\title{
Three cases of non-carryover fingolimod-PML
}

\section{Is the risk in Japan increased?}

\author{
Jin Nakahara, MD, PhD, * Laura Tomaske, MD, PhD, * Kodai Kume, MD, PhD, * Tadayuki Takata, MD, \\ Masaki Kamada, MD, PhD, Kazushi Deguchi, MD, PhD, Kenji Kufukihara, MD, Ruth Schneider, MD, PhD, \\ Ralf Gold, MD, PhD, and llya Ayzenberg, MD, PhD
}

Neurol Neuroimmunol Neuroinflamm 2019;6:e559. doi:10.1212/NXI.0000000000000559

\section{Abstract}

\section{Objective}

To report the course of 3 recent Japanese and European cases of fingolimod-associated progressive multifocal leukoencephalopathy (PML) and to analyze its risk factors and increased incidence in Japan.

\section{Methods}

Case series and literature review.

\section{Results}

Fingolimod-associated PML may cause both supratentorial and infratentorial lesions and a pronounced disability. Diagnosis can be challenging because PML lesions (especially infratentorial) can be initially misdiagnosed as extensive MS lesions. Immune reconstitution inflammatory syndrome (IRIS) develops a few weeks after fingolimod discontinuation and is usually mild. Age factor and therapy duration seem to be relevant because most reported patients were older than 45 years and were treated with fingolimod for more than 3 years. Combined IgG/IgM deficiency has been identified as a possible further predisposing condition in 1 case. Another patient developed an endogenous fungal skin infection, as a sign of generally compromised cellular immune response, shortly before PML. None of the reported patients had lymphocyte counts below 200/ $\mu$ l. Two of the 3 reported and 4 of the 21 (19\%) registered fingolimod-PML cases occurred in Japan (estimated risk of 0.652 per 1,000 compared with 0.083 per 1.000 worldwide).

\section{Conclusions}

The risk of PML under fingolimod is low, but there are no reliable predictors. Despite a mild IRIS phase, it causes profound disability. Patients older than 45 years, especially with known comorbid immunodeficiencies or manifestation of other opportunistic infections, should be monitored more closely. Increased surveillance and identification of further risk factors are urgently needed in Japan.

\author{
Correspondence \\ Dr. Ayzenberg \\ ilya.ayzenberg@rub.de
}




\section{Glossary}

ALC $=$ absolute lymphocyte count; CE = contrast enhancement; EDSS = Expanded Disability Status Scale; IRIS = immune reconstitution inflammatory syndrome; IVMP = IV methylprednisolone; JCV = JC virus; PML = progressive multifocal leukoencephalopathy; RRMS = relapsing-remitting MS.

Fingolimod (FTY, sphingosine-1-phosphate receptor modulator) sequesters circulating lymphocytes into secondary lymphoid tissues, resulting in a decrease in the absolute lymphocyte count (ALC), an inversion of the CD4/CD8 ratio, and changes in Th17 cells, regulatory $\mathrm{T}$ cells, and antigenpresenting cells. Being highly effective first-line therapy, used in more than 250,000 patients with relapsing-remitting MS (RRMS), FTY increases concerns of serious mycotic and viral infections, including progressive multifocal leukoencephalopathy (PML). ${ }^{1}$ FTY-induced decrease in IFN $\gamma$-producing $\mathrm{T}$ cells, critical for antiviral response to JC virus (JCV), and an increase in migratory capacity of B cells, as potential JCV carriers, are possible underlying mechanisms of the last one.

So far, 21 cases of non-carryover (without a previous natalizumab therapy) fingolimod-associated PML have been reported, ${ }^{2}$ yet detailed descriptions are scarce, and risk factors remain mostly unclear. ${ }^{3,4}$ Regional distribution of PML cases caused special concerns on probably increased risk in Japan. Here, we report 2 recent Japanese cases and 1 German case and discuss possible reasons of the increased incidence in Japan.

\section{Methods}

The data supporting the results of this article are contained in this published article.

\section{Results}

\section{Case 1}

A 47-year-old male Japanese patient was diagnosed with MS in 2002. There was no evidence of previous immunodeficiency or immunosuppression, except for a single cyclophosphamide infusion in 2009. He was treated with interferon- $\beta$ for 11 years and in 2013 switched to FTY. At this time point, he had no relapses and reached an Expanded Disability Status Scale (EDSS) score of 6.0 so that transition to secondary progressive MS must be assumed. The ALC maintained over 200/ $\mu$ l. Biannual MRI (November 2016) revealed a new $\mathrm{T} 2$ lesion in the cerebellar peduncle and an enlarging $\mathrm{T} 2$ lesion in the cerebral white matter near the angular gyrus, without a contrast enhancement (CE) (figure 1). He remained clinically stable and continued FTY (44 months) until late December 2016 when he exhibited word-finding difficulties with cognitive impairment akin to Gerstmann syndrome, followed by right-sided progressive hemiparesis, focal seizures, and ataxia. PML was confirmed by positive JCV-PCR in CSF (25 copies/mL), and mirtazapine and levetiracetam have been started. Follow-up MRI 4 weeks later revealed punctate $\mathrm{CE}$, compatible with immune reconstitution inflammatory syndrome (IRIS). Despite IV methylprednisolone (IVMP) with oral tapering, subsequent biweekly MRI controls revealed 2 further IRIS episodes ( 8 and 20 weeks after onset, treated with IVMP each time by an EDSS score of 8.5) (figure 1). On the last visit in June 2017, JCV-PCR was negative, and the patient stabilized with an EDSS score 7.5 and moderate cognitive impairment.

\section{Case 2}

The medical history of this 63-year-old Japanese woman with RRMS (since 2012) included no autoimmune, oncologic, or chronic infectious disease. She had low IgG and IgM levels (IgG: $593 \mathrm{mg} / \mathrm{dL}$, IgM: $26 \mathrm{mg} / \mathrm{dL}$, and IgA: $121 \mathrm{mg} / \mathrm{dL}$ ), yet no other evidence of immunodeficiency or previous immunosuppression. Despite a stable disease course (EDSS score 1.0 , no relapses), interferon $\beta$-1a has been replaced with FTY in 2013 because of depression. Her ALC ranged all the time between 400 and 600 cells/ $\mu \mathrm{L}$. In February 2016, she developed subacute progressive aphasia with severe cognitive impairments and reached an EDSS score of 5.0. MRI revealed multiple T2 lesions in the left hemisphere, involving subcortical U-fibers, without CE (figures 2, A and B). The CSF JCV load was 197 copies/mL. Despite mefloquine and mirtazapine, follow-up MRI in 4 weeks revealed massive progression of the lesions, now in both hemispheres (figure 2C). Because no contrast agent had been injected, IRIS development cannot be assessed. She achieved partial remission spontaneously 2 months later. The JCV in CSF was not detected, and cerebral lesions were slightly diminished. At the last visit in February 2018, the patient significantly improved and now lives independently despite difficulties of word recall and mild cognitive impairments (EDSS score 2.5).

\section{Case 3}

A 48-year-old Caucasian woman with RRMS (since 2001) had been switched in 2010 from glatiramer acetate to fingolimod because of ongoing disease activity with 1-2 relapses per year. Afterward, she was stable during the next 7 years (EDSS score 3.0). Neither other autoimmune, oncologic, or chronic infectious diseases nor evidence of immunodeficiency or previous immunosuppressive treatment was available. The lowest ALC was 360 cells/ $\mu \mathrm{L}$. In July 2017, she was diagnosed with pityriasis versicolor, an endogenous fungal infection of the skin, possibly indicating an insufficient T-cell-mediated immune response. In August 2017, she developed subacute progressive dysarthria, moderate cognitive dysfunction, and left hemiparesis with impaired walking (EDSS score 6.0). MRI revealed PML-suspected bihemispheric T2 lesions, 


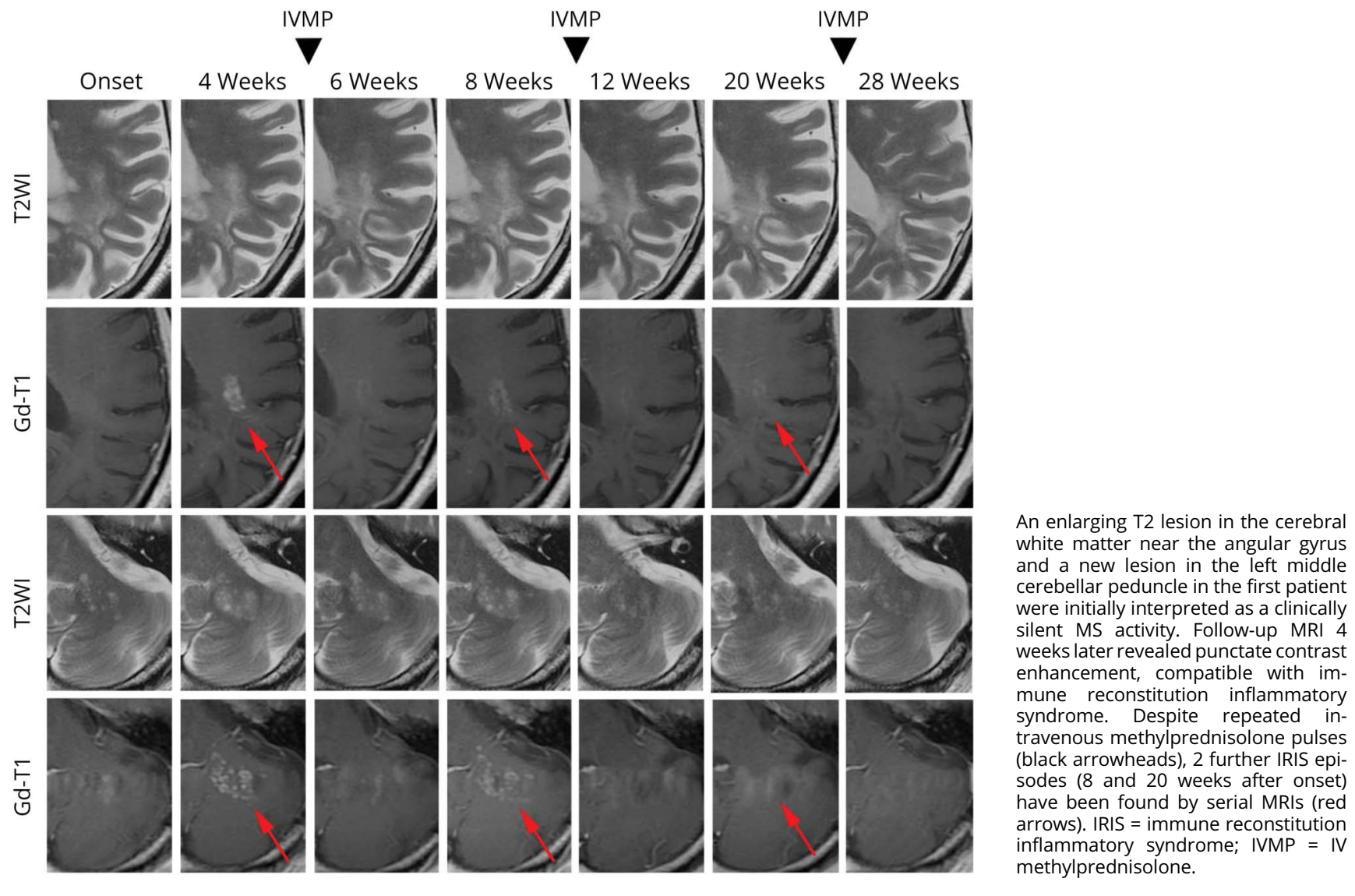

involving subcortical U-fibers (figure 2D), and JCV-PCR in CSF was positive (990 copies/mL). Fingolimod has been discontinued, and the patient was treated with mefloquine and mirtazapine. Follow-up MRI 4 weeks later showed moderate progression in the left hemisphere (figure $2 \mathrm{E}$ ) and discrete scattered punctate $\mathrm{CE}$ in the lesion margins consistent with a milder IRIS (figure 2F). Because of minimal IRIS expression and clinical stability, only the CCR5 receptor antagonist maraviroc has been administered. Her next MRI 3 months later demonstrated unchanged punctate $\mathrm{CE}$, and IVMP has been started. In April 2018, her EDSS score improved to 6.0, and frontoparietal lesions were slightly diminished. Because of a new active but clinically silent MS lesion, glatiramer acetate has been started. In June 2018, JCV-PCR in CSF was negative.

\section{Discussion}

PML is a rare but potentially dangerous complication of fingolimod. Here, we describe 3 of the 21 registered cases. Like natalizumab, both supratentorial and infratentorial lesions may occur, resulting in a pronounced disability or even fatal outcome. ${ }^{3}$ Diagnosis can be challenging because PML lesions (especially infratentorial) can be initially misdiagnosed as extensive MS lesions, repeatedly described under fingolimod. ${ }^{1}$ The IRIS phase develops a few weeks after fingolimod discontinuation. In contrast to natalizumab-PML, it is much milder, yet may be protracted. ${ }^{5}$ Of interest, fingolimod does not prevent IRIS in carryover natalizumab-PML. ${ }^{1}$

An overall low rate of fingolimod-PML allows us to speculate on probable additional predisposing immunodeficiencies. Combined IgG/IgM deficiency, immunotherapy due to inflammatory bowel diseases, and chemotherapy due to colon cancer have been reported so far. ${ }^{3,4}$ Our German patient developed an endogenous fungal skin infection, as a sign of generally compromised cellular immune response, shortly before PML. Unfortunately, there is no information concerning opportunistic infections or clinically inapparent immunodeficient conditions in further cases. ${ }^{3}$ Low ALC or previous natalizumab therapy is probably not indicative. Of interest, fingolimod can be used even after natalizumabPML. ${ }^{6}$ Age seems to be relevant, and all our patients were older than 45 years. $^{2}$ Like dimethyl fumarate, patients with fingolimod-PML are approximately 10 years older compared with those with natalizumab-PML. ${ }^{3}$ More controlled administration in relapsing MS may probably reduce the risk in older patients because 2 of the 3 patients had no relapses when fingolimod was started. Therapy duration is another important factor; our patients and $2 / 3$ of the previously registered index cases received fingolimod over 3 years. ${ }^{2,3}$ 


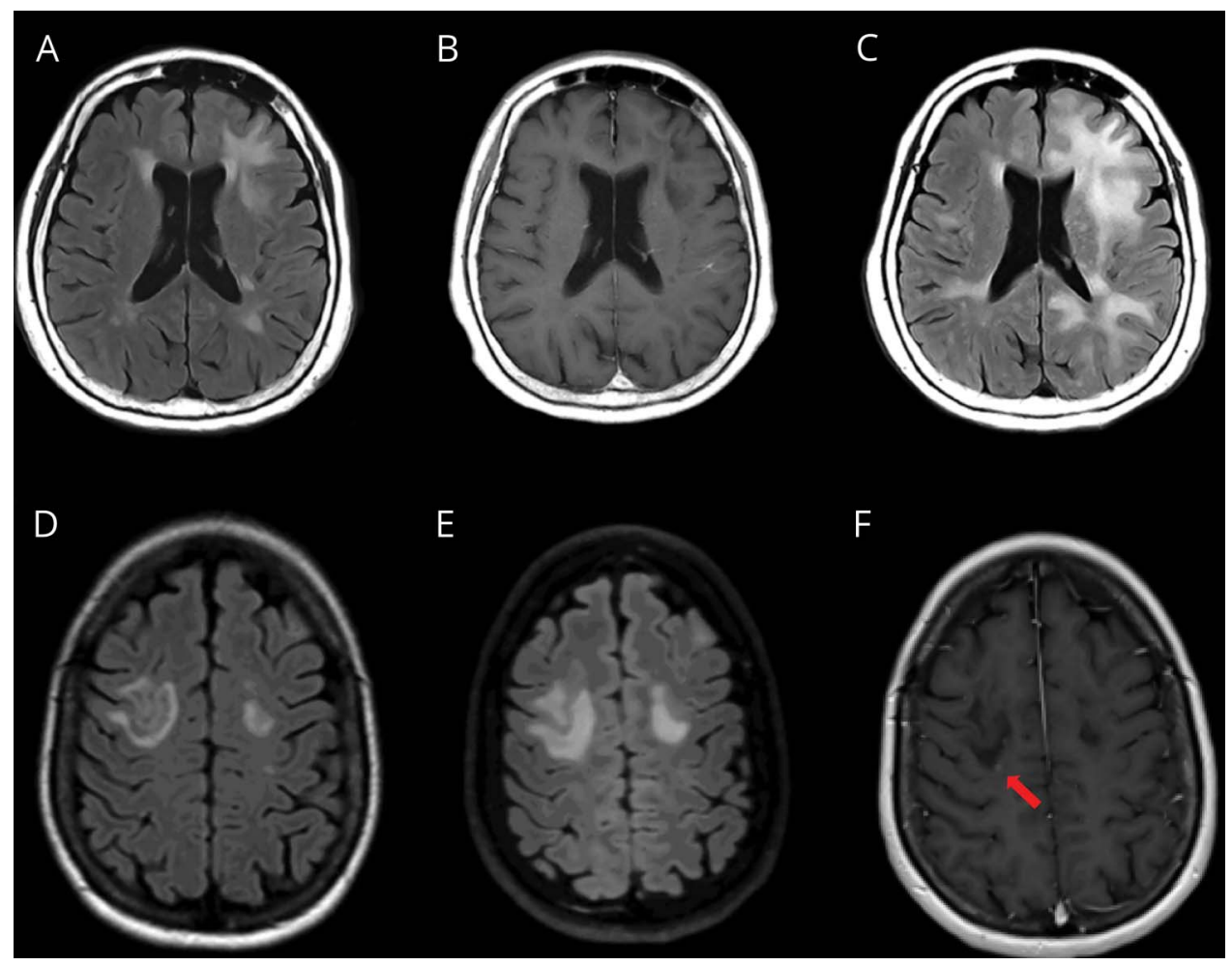

In both the second and third cases, MRI performed because of clinical deterioration revealed highly progressive multifocal leukoencephalopathy-suspicious T2 lesions involving subcortical U-fibers (A, D), without a contrast enhancement in T1 (B). Follow-up MRI 4 weeks later revealed massive progression in a second patient ( $C$, no contrast enhancement imaging performed) and only moderate enlargement in the left hemisphere in a third one (E) with discretfully scattered punctate contrast enhancement in the margins of the right-sided lesion (red arrow) consistent with a milder immune reconstitution inflammatory syndrome (F).

The risk of fingolimod-PML seems to be increased in Japan. Four of 6,138 Japanese patients on fingolimod developed PML (estimated incidence of 0.652 per 1,000 compared with 0.083 per 1.000 worldwide). ${ }^{2,7,8}$ Unfortunately, there is no information on the ethnic origin of patients in other countries. The JCV-Abs seropositivity of $70 \%-74 \%$ in Japan is higher compared with 50\%-60\% in Europe and the United States. ${ }^{9,10}$ The JCV-Abs index also increases in Japanese patients with a duration of fingolimod treatment. ${ }^{9}$ Whether this is characteristic only for this population remains unclear because no similar studies have been conducted elsewhere. An increase in the JCV$\mathrm{Ab}$ index under natalizumab was shown in Europe. ${ }^{11}$ Among 489 Japanese natalizumab-treated patients, 2 PML cases occurred so that an overall increased incidence, for example, due to immunogenetic factors, cannot be excluded. ${ }^{12}$ However, we found no such data in Japanese patients with rheumatoid diseases.

Taken together, the risk of PML under fingolimod is low, but real. Despite a mild IRIS phase, it causes profound disability. Patients older than 45 years, especially with known comorbid immunodeficiencies or manifestation of other opportunistic infections, should be monitored more closely. Biannual MRI and JCV-Ab titer control are reasonable. Increased surveillance and identification of further risk factors are urgently needed in Japan.

\section{Study funding}

No targeted funding reported.

\section{Disclosure}

J. Nakahra served on the scientific advisory boards of Biogen, Eisai, Mitsubishi Tanabe, and Novartis; received travel funding and/or speaker honoraria from Alexion, Astellas, Biogen, Daiichi Sankyo, Eisai, Fujimoto, JB, Mitsubishi Tanabe, Novartis, and Takeda; served as associate editor of Neurology and Clinical Neuroscience; holds a patent for Medicinal compositions containing $\mathrm{Fc}$ receptor $\gamma$ chain activator; and received research support from Astellas, Biogen, Boehringer Ingelheim, Daiichi Sankyo, Eisai, Kyowa Kirin, Mitsubishi Tanabe, Otsuka, Pfizer, Shionogi, Sumitomo Dainippon, UCB, Japan Society for the Promotion of Science, and Keio University. L. Tomaske received travel funding from Boehringer Ingelheim. K. Kume, T. Takata, M. Kamada, K. Deguchi, and K. Kufukihara report no disclosures. R. Schneider and R. Gold served on the scientific advisory board of Teva; received speaker honoraria from Biogen, Genzyme, Teva, Merck Serono, Bayer Schering, Celgene, and Novartis; and served on the editorial boards of SAGE Journal, Aktuelle Neurologie, and Experimental Neurology. I. Ayzenberg served on the scientific advisory boards of Roche and Merck and received travel funding from Biogen and speaker honoraria from Santhera. Disclosures available: Neurology.org/NN.

\section{Publication history}

Received by Neurology: Neuroimmunology \& Neuroinflammation October 10, 2018. Accepted in final form February 19, 2019. 


\section{Appendix Author contributions}

\begin{tabular}{|c|c|c|c|}
\hline Name & Location & Role & Contribution \\
\hline $\begin{array}{l}\text { Jin } \\
\text { Nakahara, } \\
\text { MD, PhD }\end{array}$ & $\begin{array}{l}\text { Department of } \\
\text { Neurology, Keio } \\
\text { University School of } \\
\text { Medicine, Tokyo, } \\
\text { Japan }\end{array}$ & Author & $\begin{array}{l}\text { Diagnosis and } \\
\text { treatment of PML and } \\
\text { MRI data collection in } \\
\text { case } 1\end{array}$ \\
\hline $\begin{array}{l}\text { Laura } \\
\text { Tomaske }\end{array}$ & $\begin{array}{l}\text { Department of } \\
\text { Neurology, St. Josef } \\
\text { Hospital, Ruhr } \\
\text { University Bochum, } \\
\text { Bochum, Germany }\end{array}$ & Author & $\begin{array}{l}\text { Diagnosis and } \\
\text { treatment of PML in } \\
\text { case } 3 \text {, analysis of } \\
\text { clinical information, } \\
\text { and revision of the } \\
\text { manuscript }\end{array}$ \\
\hline $\begin{array}{l}\text { Kodai } \\
\text { Kume, MD, } \\
\text { PhD }\end{array}$ & $\begin{array}{l}\text { Department of } \\
\text { Gastroenterology and } \\
\text { Neurology, Kagawa } \\
\text { University Faculty of } \\
\text { Medicine, Kagawa, } \\
\text { Japan }\end{array}$ & Author & $\begin{array}{l}\text { Diagnosis and } \\
\text { treatment of PML and } \\
\text { MRI data collection in } \\
\text { case } 2\end{array}$ \\
\hline $\begin{array}{l}\text { Tadayuki } \\
\text { Takata, MD }\end{array}$ & $\begin{array}{l}\text { Department of } \\
\text { Gastroenterology and } \\
\text { Neurology, Kagawa } \\
\text { University Faculty of } \\
\text { Medicine, Kagawa, } \\
\text { Japan }\end{array}$ & Author & $\begin{array}{l}\text { Diagnosis and } \\
\text { treatment of PML and } \\
\text { MRI data collection in } \\
\text { case } 2\end{array}$ \\
\hline $\begin{array}{l}\text { Masaki } \\
\text { Kamada, } \\
\text { MD, PhD }\end{array}$ & $\begin{array}{l}\text { Department of } \\
\text { Intractable } \\
\text { Neurological } \\
\text { Research, Faculty of } \\
\text { Medicine, Kagawa } \\
\text { University }\end{array}$ & Author & $\begin{array}{l}\text { Diagnosis and } \\
\text { treatment of PML and } \\
\text { MRI data collection in } \\
\text { case } 2\end{array}$ \\
\hline $\begin{array}{l}\text { Kazushi } \\
\text { Deguchi, } \\
\text { MD, PhD }\end{array}$ & $\begin{array}{l}\text { Department of } \\
\text { Gastroenterology and } \\
\text { Neurology, Kagawa } \\
\text { University Faculty of } \\
\text { Medicine, Kagawa, } \\
\text { Japan }\end{array}$ & Author & $\begin{array}{l}\text { Diagnosis and } \\
\text { treatment of PML and } \\
\text { MRI data collection in } \\
\text { case } 2\end{array}$ \\
\hline $\begin{array}{l}\text { Kenji } \\
\text { Kufukihara, } \\
\text { MD }\end{array}$ & $\begin{array}{l}\text { Department of } \\
\text { Neurology, Keio } \\
\text { University School of } \\
\text { Medicine, Tokyo, } \\
\text { Japan }\end{array}$ & Author & $\begin{array}{l}\text { Analysis of clinical } \\
\text { information and MRI } \\
\text { data collection in case } \\
1\end{array}$ \\
\hline $\begin{array}{l}\text { Ruth } \\
\text { Schneider }\end{array}$ & $\begin{array}{l}\text { Department of } \\
\text { Neurology, St. Josef } \\
\text { Hospital, Ruhr } \\
\text { University Bochum, } \\
\text { Bochum, Germany }\end{array}$ & Author & $\begin{array}{l}\text { MRI data collection, } \\
\text { analysis of clinical } \\
\text { information, and MRI } \\
\text { data collection in case } \\
3\end{array}$ \\
\hline Ralf Gold & $\begin{array}{l}\text { Department of } \\
\text { Neurology, St. Josef } \\
\text { Hospital, Ruhr } \\
\text { University Bochum, } \\
\text { Bochum, Germany }\end{array}$ & Author & $\begin{array}{l}\text { Diagnosis and } \\
\text { treatment of PML, } \\
\text { MRI data collection in } \\
\text { case } 3 \text {, and revision of } \\
\text { the manuscript }\end{array}$ \\
\hline $\begin{array}{l}\text { Ilya } \\
\text { Ayzenberg, } \\
\text { MD, PhD }\end{array}$ & $\begin{array}{l}\text { Department of } \\
\text { Neurology, St. Josef } \\
\text { Hospital, Ruhr } \\
\text { University Bochum, } \\
\text { Bochum, Germany; } \\
\text { Department of } \\
\text { Neurology, Sechenov } \\
\text { First Moscow State } \\
\text { Medical University, } \\
\text { Moscow, Russia }\end{array}$ & $\begin{array}{l}\text { Corresponding } \\
\text { author }\end{array}$ & $\begin{array}{l}\text { Design and } \\
\text { conceptualization of } \\
\text { the report, analysis of } \\
\text { data, and drafting of } \\
\text { the manuscript }\end{array}$ \\
\hline
\end{tabular}

\section{References}

1. Yoshii F, Moriya Y, Ohnuki T, Ryo M, Takahashi W. Neurological safety of fingolimod: an updated review. Clin Exp Neuroimmunol 2017;8:233-243.

2. Ontaneda D, Moore A, Bakshi R, Zajicheck A, Kattan M, Fox R. Risk estimates of progressive multifocal leukoencephalopathy related to fingolimod [Abstract P1775]. Mult Scler 2018;24(2 suppl):981-1026.

3. Berger JR, Cree BA, Greenberg B, et al. Progressive multifocal leukoencephalopathy after fingolimod treatment. Neurology 2018;90:e1815-e1821.

4. Gyang TV, Hamel J, Goodman AD, Gross RA, Samkoff L. Fingolimod-associated PML in a patient with prior immunosuppression. Neurology 2016;86:1843-1845.

5. Nishiyama S, Misu T, Shishido-Hara Y, et al. Fingolimod-associated PML with mild IRIS in MS: a clinicopathologic study. Neurol Neuroimmunol Neuroinflamm 2018;5:e415.

6. Peaureaux D, Pignolet B, Biotti D, et al. Fingolimod treatment after natalizumab-related progressive multifocal leukoencephalopathy: three new cases. Mult Scler 2015;21:671-672.

7. Novartis Japan. Side effects of fingolimod. Available at: drs-net.novartis.co.jp/SysSiteAssets/common/pdf/gil/ts/ts gil pms jisshijokyo 20181130.pdf; drs-net.novartis. co.jp/SysSiteAssets/common/pdf/gil/ts/ts_gil_pms_fukusayo_20181130.pdf. Accessed November 30, 2018.

8. Mori M, Uzawa A, Otani R, et al. 4th PML-case in Japanese multiple sclerosis patient treated with fingolimod. Proceedings of the 59th Annual Meeting of the Japanese Society of Neurology 2018;59:338.

9. Aoyama S, Mori M, Uzawa A, et al. Serum anti-JCV antibody indexes in Japanese patients with multiple sclerosis: elevations along with fingolimod treatment duration. J Neurol 2018;265:1145-1150.

10. Paz SPC, Branco L, Pereira MAC, Spessotto C, Fragoso YD. Systematic review of the published data on the worldwide prevalence of John Cunningham virus in patients with multiple sclerosis and neuromyelitis optica. Epidemiol Health 2018;40: e2018001.

11. Raffel J, Gafson AR, Malik O, Nicholas R. Anti-JC virus antibody titres increase over time with natalizumab treatment. Mult Scler 2015;21:1833-1838.

12. Biogen, Side effects of Natalizumab. Available at: tys.ms-supportnavi.com/ja-jp/ home/safety/safety02.html. Accessed February 16, 2018. 


\section{Neurology \\ Neuroimmunology \& Neuroinflammation}

Three cases of non-carryover fingolimod-PML: Is the risk in Japan increased?

Jin Nakahara, Laura Tomaske, Kodai Kume, et al.

Neurol Neuroimmunol Neuroinflamm 2019;6;

DOI 10.1212/NXI.0000000000000559

This information is current as of April 10, 2019

\section{Updated Information \& Services}

References

Permissions \& Licensing including high resolution figures, can be found at: http://nn.neurology.org/content/6/3/e559.full.html

This article cites 9 articles, 0 of which you can access for free at: http://nn.neurology.org/content/6/3/e559.full.html\#\#ref-list-1

Information about reproducing this article in parts (figures,tables) or in its entirety can be found online at:

http://nn.neurology.org/misc/about.xhtml\#permissions

Information about ordering reprints can be found online: http://nn.neurology.org/misc/addir.xhtml\#reprintsus

Neurol Neuroimmunol Neuroinflamm is an official journal of the American Academy of Neurology.

Published since April 2014, it is an open-access, online-only, continuous publication journal. Copyright

Copyright (C) 2019 The Author(s). Published by Wolters Kluwer Health, Inc. on behalf of the American Academy of Neurology.. All rights reserved. Online ISSN: 2332-7812.

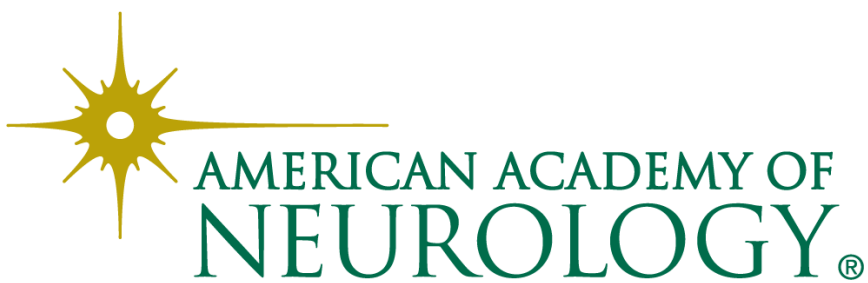

